\title{
Infection Control Practices for Preventing Respiratory Syncytial Virus Infections
}

\author{
CDR Robert Lee Brawley, MC, USN
}

Respiratory syncytial virus (RSV) is the major pathogen causing community-acquired or nosocomial lower respiratory tract infections among infants and children. ${ }^{1-3}$ With distinct regularity, epidemics of acute respiratory disease associated with RSV occur each winter and last two to five months. Virtually all children develop RSV infections by age $5 .^{1}$ The peak occurrence of bronchiolitis or pneumonia in outpatient settings ${ }^{4}$ and increased admissions of children with lower respiratory tract diseases" herald the arrival of RSV within a community.

Respiratory syncytial virus spreads easily through exposed families, with infants developing the most severe diseases. School-aged children with mild upper respiratory infections most often introduce the virus into families, with infants becoming secondarily infected.1,6 Mothers of infants admitted with RSV infections may also be culture positive for $\operatorname{RSV}^{7,8}$ Intrafamilial spread is thought to occur by contact with large droplets or through fomites, or by contact with contaminated secretions, much like the spread of rhinoviruses.'

RSV has been estimated to cause $5 \%$ to $40 \%$ of pneumonias among young children, and $50 \%$ to $90 \%$ of bronchiolitis. In normal children, RSV lower respiratory tract diseases usually occur in children under age 2 . In some locations, approximately 1 of every 100 infants two to five months old with primary RSV infections will be hospitalized for bronchiolitis.'

Infection may spread rapidly in newborn nurseries, especially among premature infants, although illness may be either mild or atypical (eg, severe apnea). 8,9 Prospective surveillance during the RSV season and rapid diagnosis using immunofluorescence methods allows for early isolation and cohorting of RSV-infected infants. ${ }^{10,11}$ In Rochester, New York the frequency of nosocomial RSV infections in infants during community epidemics has ranged between $19 \%$ and $45 \% .{ }^{12}$

Address reprint requests to CDR Robert L. Brawley, MC, USN, Occupational Health/Preventive Medicine Department, Naval Medical Clinic, San Francisco. CA 94130.5030.
Severe or fatal RSV infections may occur in high-risk infants with prematurity, ${ }^{9}$ perinatal complications," congenital heart disease, ${ }^{13,14}$ other congenital anomalies, ${ }^{14}$ or primary immunodeficiency disorders, and in children after chemotherapy for cancer. ${ }^{15}$ Infants at high risk for severe complications due to RSV infections should not be electively admitted to the hospital during a known RSV outbreak unless they can receive appropriate isolation.

Control of nosocomial RSV transmission has been directed at interrupting spread of the virus by direct contact with large particles or droplets or by fomites or self-inoculation of RSV-infected secretions into the eye or nasal mucosa. ${ }^{16}{ }^{18}$ These studies have demonstrated that RSV may survive for several hours in the hospital environment and may be recovered from hands that have touched contaminated surfaces.

Prospective controlled studies using gowns and masks to supplement good handwashing failed to demonstrate any differences in the frequency of nosocomial RSV transmission to infants ${ }^{19}$ or hospital personnel ${ }^{19,20}$ compared with handwashing alone.

Glove and gown precautions, in a recent longitudinal intervention study, have been shown to substantially reduce nosocomial RSV transmission to patients on an infant and toddler ward. The risk of acquiring nosocomial RSV infection was almost three times greater during the period when gown and glove precautions were least utilized. Nosocomial RSV transmission to the hospital staff was not studied. An educational campaign introduced by the ward's head nurse provided sustained compliance with these glove and gown precautions after the study ended. ${ }^{21}$

Reduction of nosocomial RSV transmission to hospital staff has been demonstrated using barriers against inoculation of RSV-infected secretions into the eyes and nose. ${ }^{12,22}$ The ingenious use of disposable eyenose goggles was associated with a significant decrease in nosocomial RSV transmission to both hospital staff and susceptible infants. The frequency of nosocomial RSV transmission was five to seven times greater, respectively, during the study interval without the eyenose goggles. ${ }^{12}$ Masks and goggles significantly decreased RSV illnesses 
among pediatric health care workers for those not using masks and goggles from $61 \%$ to $5 \% .^{22}$

Snydman and colleagues demonstrated that the institution of multiple infection control procedures, including active surveillance, cohorting infected patients, a strict winter visiting policy, good handwashing, use of gowns, gloves, and masks, were successful in preventing nosocomial RSV transmission among patients in a newborn nursery (see pp 105-108). ${ }^{23}$ This program successfully prevented an RSV epidemic like the ones that resulted in closure of the ward during the three previous RSV seasons. Transmission of RSV among hospital personnel in the nursery was not studied.

$\mathrm{H}$ all et al formerly studied similar infection control measures except for gloves and masks, but compared data from the study period to data from the previous RSV season. Compared with the historical controls, nosocomial RSV transmission decreased from $45 \%$ to $19 \%$ among infants. Nosocomial RSV transmission rates to hospital staff were unchanged at about $50 \% .24$

The goal of an infection control program for RSV should be to limit nosocomial transmission of this virus to both hospital staff and susceptible infants and children, especially those at high risk for complications or death. What approach is best? Combining the features of the study by Snydman et al with wearing goggles when having contact with RSV-infected patients may be most effective. Eye-nose goggles, combined with good handwashing, respiratory isolation, and cohorting of proven RSV infections would be advantageous if their efficacy is confirmed by a longitudinal study.

\section{REFERENCES}

1. Hall CR: Respiratory syncytial virus, in Feigin RD, Cherry JD (eds): Textbook of Pediatric Infectious Diseases, ed 2. Philadelphia, W.B. Saunders Co, 1987, pp $1653-1676$.

2. Hall CB: Nosocomial viral respiratory infections: Perennial weeds on pediatric wards. Am J Med 1981; 70:670-676.

3. Welliver KC, McLaughlin S: Unique epidemiology of nosocomial infection in a children's hospital. Am J Dis Child 1984: 138:131-135.
4. Hall CB, Douglas RG Jr: Respiratory, syncytial virus and influenza: Practical community surveillance. Am / Dis Child 1976; 130:615-620.

5. Kim HW, Arrobio JO. Brandt CD, et al: Epidemiology of respiratory syncytial virus infection in Washington. DC. I. Importance of the virus in different respiratory disease syndromes and temporal distribution of infection. Am $J$ Epidemial 1973; 98:216-225.

6. Sims DG, Downham MAPS, McQuillin J, et al: Respiratory syncytial virus infection in north-east England Br Med J 1976; 2:1095-1098.

7. Sims DG. Downham MAPS, Wehh JDG, et al: Hospital cross-infection on children's wards with respiratory syncytiat virus and the role of adult carriage. Acta Paediatr Scand 1975; 64:541-545.

8. Goldson EJ. McCarthy JT, Welling MA, et al: A respiratory syncytial virus outbreak in a transitional care nursery. Am I Dis Child 1979: 133:1280-1282.

9. Hall $\mathrm{CB}$, Kopelman $\mathrm{AE}$, Douglas $\mathrm{KC}$; Jr, et al: Neonatal respiratory syncytial virus infection. $N$ Engl J Med 1979:300:393-396.

10. Friedman AD, Naqvi SH, Arens MQ, et al: Value of rapid diagnosis of respiratory syncytiat virus infection on management of small infants. Clin Pediatr 1986; 25:404-406.

11. Eriksson M, Forsgren M, Sjoberg $S$, et al: Respiratory syncytial virus infection in young hospitalized children: Identification of risk patients and prevention of nosocomial spread by rapid diagnosis. Acta Paediatr Scand 1983; 72:47-51.

12. Gala CL. Halt CB, Schnable KC, et al: The use of eye-nose goggles to control nosocomial respiratory syncytiat virus infection. JAMA 1986; 256:2706-2708.

13. MacDonald NE, Hall CB, Suffin SC, et al: Respiratory syncytial viral infection in infants with congenital heart disease. N Engl J Med 1982; 307:397-400

14. Krasinski K: Severe respiratory syncytial virus infection: Clinical features, nosocomiat acquisition and outcome. Pediatr Infect Dis 1985; 4:250-257.

15. Hall CB, Powell KR, MacDonald NE, et al: Respiratory synrytial viral infection in children with compromised immunc function. $N$ Engl / Med 1986; 315:77-81.

16. Hall CB: The nosocomial spread of respiratory syncytial viral infections. Ann Rev Med 1983; 34:311-319.

17. Hall CR, Douglas RG.Jr: Modes of transmission of respiratory syncytial virus. J Pediatr 1981; 99:100-103.

18 Hall CB, Douglas RG Jr, Geiman JM: Possible transmission by fomites of respiratory syncytiat virus. J Infect Dis 1980; 141:98-102.

19 Hall CB, Douglas RC; Jr: Nosocomial respiratory syncytial viral infections: Should gowns and masks he used? Am I Dis Child 1981; 135:512-515.

20 Murphy I), Todd JK, Chao RK, et al: The use of gowns and masks to control respiratory illness in pediatric hospital personnel. J Pediatr 1981; 99:746-750.

21 Leclair IM, Freeman J, Sullivan RF, et al: Prevention of nosocomial respiratory syncytial virus infections thorugh compliance with glow and gown isolation precautions. N EnglJ Med 1987; 317:329-334.

22 Agah R, Cherry JD, Garakian AJ, et al: Respiratory syncytial virus (RSV) infection rate in personnel caring for children with RSV infections: Routine isolation procedure vs. routine procedure supplemented by use of masks and goggles. Am J Dis Chiid 1987; 141:695-697.

23 Snydman DR, Greer C, Meissner HC, et al: Prevention of nosocomial transmission of respiratory syncytial virus in a newborn nursery. Infect Control Hosp Epidemiol 1988; 9:105-108.

24 Hall CB, Geiman JM, Douglas RG Jr, et al: Control of nosocomial respiratory syncytial viral infections. Pediatrics 1978: 62:728-732. 